\title{
Article \\ Effects of Bamboo (Phyllostachys praecox) Cultivation on Soil Nitrogen Fractions and Mineralization
}

\author{
Zhuangzhuang Qian ${ }^{1,+}$, Xiao Sun ${ }^{2,+}$, Jianshuang Gao ${ }^{1}$ and Shunyao Zhuang ${ }^{1, *}$ \\ 1 State Key Lab of Soil and Sustainable Agriculture, Institute of Soil Science, Chinese Academy of Sciences, \\ 71 East-Beijing Road, Nanjing 210008, China; zzqian@njfu.edu.cn (Z.Q.); gaojianshuang@issas.ac.cn (J.G.) \\ 2 College of Chemistry and Materials Science, Ludong University, Yantai 264025, China; hellosunxiao@163.com \\ * Correspondence: syzhuang@issas.ac.cn; Tel.: +86-25-86881103; Fax: +86-25-86881000 \\ + Qian Z.Z. and Sun X. contributed equally to this work and should be considered co-first authors.
}

Citation: Qian, Z.; Sun, X.; Gao, J.;

Zhuang, S. Effects of Bamboo

(Phyllostachys praecox) Cultivation on Soil Nitrogen Fractions and

Mineralization. Forests 2021, 12, 1109 https://doi.org/10.3390/f12081109

Academic Editor:

Simone Aparecida Vieira

Received: 27 July 2021

Accepted: 17 August 2021

Published: 19 August 2021

Publisher's Note: MDPI stays neutral with regard to jurisdictional claims in published maps and institutional affiliations.

Copyright: (c) 2021 by the authors. Licensee MDPI, Basel, Switzerland. This article is an open access article distributed under the terms and conditions of the Creative Commons Attribution (CC BY) license (https:// creativecommons.org/licenses/by/ $4.0 /)$.
Abstract: The mineralization of soil organic nitrogen $(\mathrm{N})$ is the key process in the cycling of $\mathrm{N}$ in terrestrial ecosystems. Land-use change to bamboo (Phyllostachys praecox) cultivation that later entails organic material mulching combined with chemical fertilizer application will inevitably influence soil $\mathrm{N}$ mineralization $\left(\mathrm{N}_{\min }\right)$ and availability dynamics. However, the soil $\mathrm{N}_{\min }$ rates associated with various $\mathrm{N}$ fractions of P. praecox in response to land-use change and mulching are not well understood. The present study aimed to understand the effects of land-use change to P. praecox bamboo cultivation and organic material mulching on soil $\mathrm{N}_{\min }$ and availability. Soil properties and organic $\mathrm{N}$ fractions were measured in a P. praecox field planted on former paddy fields, a mulched P. praecox field, and a rice (Oryza sativa L.) field. Soil $\mathrm{N}_{\min }$ was determined using a batch incubation method, with mathematical models used to predict soil $\mathrm{N}_{\min }$ kinetics and potential. The conversion from a paddy field to P. praecox plantation decreased the soil $\mathrm{pH}$, soil total $\mathrm{N}$, and soil organic matter (SOM) content significantly $(p<0.05)$; the mulching method induced further soil acidification. The mulching treatment significantly augmented the SOM content by $7.08 \%$ compared with the no-mulching treatment $(p<0.05)$, but it decreased soil hydrolyzable $\mathrm{N}$ and increased the nonhydrolyzable $\mathrm{N}(\mathrm{NHN})$ content. Both the $\mathrm{N}_{\min }$ rate and cumulative mineralized $\mathrm{N}$ were lowest in the mulched bamboo field. The kinetics of $\mathrm{N}_{\min }$ was best described by the 'two-pool model' and 'special model'. The Pearson's correlation analysis and the Mantel test suggested soil pH was the dominant factor controlling the soil cumulative mineralized $\mathrm{N}$ and mineralization potential in the bamboo fields. These findings could help us better understand the $\mathrm{N}$ cycling and $\mathrm{N}$ availability under mulching conditions for shifts in land use, and provide a scientific basis for the sustainable management of bamboo plantations.

Keywords: kinetic equations; nitrogen mineralization; organic material mulching; organic nitrogen fraction; Phyllostachys praecox; soil acidification

\section{Introduction}

Nitrogen $(\mathrm{N})$ is a limiting factor for the growth and development of plants as well as a robust indicator of soil fertility [1,2]. In terrestrial ecosystems, $\mathrm{N}$ mainly exists in organic forms in which its availability is restricted by its chemical composition and structure [3]. Soil organic $\mathrm{N}$ can be divided into hydrolyzable $\mathrm{N}$ (THN) and nonhydrolyzable $\mathrm{N}$ (NHN) components via a chemical extraction method; the forms of THN include ammonium $\mathrm{N}(\mathrm{AN})$, amino acid $\mathrm{N}$ (AAN), amino sugar $\mathrm{N}$ (ASN), and unknown hydrolyzable $\mathrm{N}(\mathrm{UHN})[4,5]$. Because of its rapid turnover and high proportion in soil $\mathrm{N}$, the AAN is considered an important indicator of $\mathrm{N}$ cycling and the state of organic matter degradation [6,7]. Accordingly, soil $\mathrm{N}$ fractionation is a widely accepted method for identifying the potential bioavailability of nitrogen [8]. Although some THNs can be directly absorbed by plants or assimilated by microorganisms, most soil organic $\mathrm{N}$ must first be converted into nitrate $\mathrm{N}\left(\mathrm{NO}_{3}{ }^{-}-\mathrm{N}\right)$ and ammonium $\mathrm{N}\left(\mathrm{NH}_{4}{ }^{+}-\mathrm{N}\right)$ by mineralization before it can be 
absorbed and utilized by plants [9]. Furthermore, this mineralization process can also affect the dynamics of soil $\mathrm{N}$ leaching and its gaseous losses [10]. Thus, $\mathrm{N}$ mineralization $\left(\mathrm{N}_{\min }\right)$ rates can better convey changes in soil quality and ecosystem functions [11].

Soil $\mathrm{N}_{\min }$ is strongly influenced by various abiotic factors, such as temperature, moisture, $\mathrm{pH}$, and fertility levels [12-14]. Moisture and temperature are two well-known major factors controlling $\mathrm{N}_{\min }$; moreover, Neina [15] reported that $\mathrm{N}_{\min }$ mainly occurs at a $\mathrm{pH}$ of 6.5-8. Nitrification is quite sensitive to soil $\mathrm{pH}$ values; generally, raising the soil $\mathrm{pH}$ can increase the amount of soluble soil organic matter (SOM), which provides $\mathrm{C}$ and $\mathrm{N}$ substrates for microbes, thereby increasing both microbial diversity and soil enzyme activity $[16,17]$. Yet, it was also reported that nitrification can occur rapidly within the $\mathrm{pH}$ range of 4.5-5.2 [18]. Both the amount and forms of SOM can also have substantial impacts upon $\mathrm{N}_{\min }$, especially the labile $\mathrm{C}$ and $\mathrm{N}$ pools, given the positive correlation between the mineralization potential and SOM content [19]. Ros [20] concluded that $\mathrm{N}_{\text {min }}$ is primarily related to the size of SOM and extractable organic matter fractions, whereas those variables corresponding to soil texture and organic matter quality are deemed less important. However earlier, Bechtold and Naiman [21] found that $\mathrm{N}_{\min }$ was maximal in fine-textured soil samples under long-term laboratory incubation, and went on to suggest that particle size influenced the $\mathrm{N}$ content and its mineralization. Thus, it is not a single factor that determines $\mathrm{N}_{\min }$, but rather a variety of factors capable of exerting interactive effects upon $\mathrm{N}_{\min }$ dynamics. In addition to the local environment and soil factors, soil $\mathrm{N}_{\text {min }}$ can vary considerably among locations due to their cultivated plant species and management practices [22]. In particular, land-use changes involving the planting of different species often entail a combination of different forms of management. In this respect, the sudden and heavy input of organic manure and fertilizers ( $\mathrm{N}$ fertilizer) is especially relevant, as it can seriously affect the amount and the cycling of soil $\mathrm{N}$.

Paddy rice production is one of the traditional land-use systems in South China due to the high population [23], but the increase of the rice yield has inhibited the price of the rice. Therefore, in the last few decades, with the goal of improving the local economy, increasingly more agricultural land in South China is undergoing conversion to Phyllostachys praecox bamboo plantations [24]. Since its shoots are edible by humans, $P$. praecox is a favored species, and because of its high economic returns, P. praecox plantations are now extensively cultivated in southern China [25]. Intensive management techniques for its cultivation there include organic material mulching, heavy fertilization, and the application of organic manure, all of which are commonly used to increase soil temperatures in winter so as to stimulate the early emergence of bamboo shoots and obtain a premium price when the market supply is low [26]. As reported by other researchers, mulching can foster soil organic matter accumulation and lead to soil acidification, as well as bamboo recession [27-29]. In general, the high content of SOM ought to increase the soil $\mathrm{N}_{\min }$ [30], but a low $\mathrm{pH}$ could reduce the potential $\mathrm{N}$ mineralization rate [31]. Accordingly, the soil $\mathrm{N}_{\text {min }}$ potential of P. praecox plantations can be complicated under conditions of mulching applications, making it hard to predict, especially since it has not yet be robustly elucidated.

Mineralization of soil organic $\mathrm{N}$ in bamboo soils is the key process underpinning $\mathrm{N}$ nutrition. When land-use change is followed with organic mulching materials combined with chemical fertilizer application, this is apt to influence soil $\mathrm{N}$ availability. However, despite the prevalence of bamboo plantations worldwide, how the soil organic $\mathrm{N}$ fraction and $\mathrm{N}_{\min }$ rates of $P$. praecox fields have responded to land-use changes and mulching remain poorly understood. Here we hypothesized that land-use change could significantly change the soil $\mathrm{N}$ forms and $\mathrm{N}_{\min }$ of bamboo-cultivated soil. At the same time, the organic material mulching technique would further reduce soil $\mathrm{N}$ availability because of severe soil acidification. Therefore, the objectives of this study were: (1) to investigate the effects of bamboo plantation establishment and its organic material mulching on the soil $\mathrm{N}$ fraction and $\mathrm{N}_{\min }$ rate; (2) to evaluate the soil $\mathrm{N}$ availability potential by using kinetic models of $\mathrm{N}_{\min }$; (3) to explore the joint, comprehensive impacts of soil organic matter and soil $\mathrm{pH}$ upon $\mathrm{N}_{\min }$. The empirical determination of the soil organic $\mathrm{N}$ fraction and $\mathrm{N}_{\min }$ rate 
advances our understanding of the effects of mulching on N-use efficiency and $\mathrm{N}$ cycling in plantation settings. Moreover, it could provide a timely reference for moving closer to the sustainable production of P. praecox in practice.

\section{Materials and Methods}

\subsection{Study Area}

The soil samples were collected from the Lin'an District of Hangzhou City, Zhejiang Province, China ( $\left.30^{\circ} 17^{\prime} 17^{\prime \prime} \mathrm{N}, 119^{\circ} 32^{\prime} 44^{\prime \prime} \mathrm{E}\right)$. The study area is within a subtropical monsoon climate zone, and has an annual precipitation of $1420 \mathrm{~mm}$ and an annual average temperature of $15.9^{\circ} \mathrm{C}$. The soil texture is medium loam and the soil type is classified as Anthrosols according to the FAO (Food and Agriculture Organization).

An area of about $4 \mathrm{~km}^{2}$ was selected for this study. Due to economic and historical reasons, some of the paddy fields were converted to P. praecox stands in recent years and these two different land-use systems (paddy fields and Phyllostachys praecox plantations) were distributed randomly in this area. P. praecox plantations shared the same soil texture with paddy fields before the conversion of the rice fields into bamboo plantations.

\subsection{Experimental Design and Organic Mulching Technique}

Our study contained two P. praecox plantations including a mulching treatment (mulched in 2015 and 2017, PM) and a nonmulching treatment (PNM); in this area, the two $P$. praecox plantations were planted on fields no longer used for rice paddy farming since 2010. The bamboo culm density of the PM and PNM was 1.51 stems $\mathrm{m}^{-2}$ and 1.31 stems $\mathrm{m}^{-2}$, respectively; the mean diameter at breast height of the P. praecox bamboo in the PM and PNM was $4.67 \mathrm{~cm}$ and $3.65 \mathrm{~cm}$, respectively. The still-farmed paddy field (PS) was randomly chosen as a control. Within each treatment, three plots (each $200 \mathrm{~m}^{2}$ ) were established for sampling. For the paddy field, the fertilization rate was $375 \mathrm{~kg} \mathrm{~N} \mathrm{ha}^{-1}$ year $^{-1}$ and the rice was harvested in early November of each year. For the P. praecox plantation without mulching, its fertilization rate was $150 \mathrm{~kg} \mathrm{~N} \mathrm{ha}^{-1}$ year $^{-1}$. For the P. praecox plantation with mulching, an organic material mulching technique was applied. In brief, this mulching involved placing $10-15 \mathrm{~cm}$ of rice straw (42.18\% organic carbon (OC), $0.78 \%$ total $\mathrm{N}(\mathrm{TN})$ ) on the soil surface, then adding $10-15 \mathrm{~cm}$ of rice husks $(35.86 \%$ OC, $0.47 \% \mathrm{TN})$ to form a thick mulch. The yearly application amount of these mulching materials was equivalent to $40 \mathrm{Mg} \mathrm{ha}^{-1}$ of rice straw and $55 \mathrm{Mg} \mathrm{ha}^{-1}$ of rice husk. In the present study, the mulching period started in December and terminated in March of the next year. After March, the mulching materials were removed as much as possible. A high fertilization rate, comprising $1125 \mathrm{~kg} \mathrm{ha}^{-1}$ of urea and $2250 \mathrm{~kg} \mathrm{ha}^{-1}$ of complex fertilizer (N-P-K: 16-16-16), was applied every year prior to mulching.

\subsection{Soil Sampling and Sample Assay}

All the soil samples were collected in November 2018. The soil $(0-20 \mathrm{~cm}$ depth) was collected from five randomly selected locations within each plot and combined to form a composite sample. These nine soil samples were air-dried, ground, and sieved for their later analysis. Soil $\mathrm{pH}$ was measured in 1:2.5 $(w / v)$ distilled deionized water by a FE28-Standard $\mathrm{pH}$ meter (METTLER TOLEDO Co., Ltd., Shanghai, China); SOM was determined by the heating digestion method with $5 \% \mathrm{~K}_{2} \mathrm{Cr}_{2} \mathrm{O}_{7}$ and $\mathrm{H}_{2} \mathrm{SO}_{4}$ [32]. Soil TN was determined by the Kjeldahl method; soil $\mathrm{NH}_{4}{ }^{+}-\mathrm{N}$ and $\mathrm{NO}_{3}{ }^{-}-\mathrm{N}$ were each extracted by $2 \mathrm{M} \mathrm{KCL}$ and respectively quantified by indophenol blue colorimetry and dual wavelength colorimetry [33]. The soil basic properties of the three sites are summarized in Table 1.

\subsection{Incubation Experiment and Measurement of Soil Nitrogen Mineralization}

An aerobic incubation method with intermittent leaching was used to determine $\mathrm{N}$ mineralization $\left(\mathrm{N}_{\min }\right)$ [34]. Briefly, a layer of glass wool was first placed at the bottom of a 50-mL cylinder vial, then quartz sand ( $15 \mathrm{~g}$ ) was added on top of it, and another layer of glass wool placed on that sand, above which a homogeneous mixed sample of air-dried soil 
$(15 \mathrm{~g})$ and quartz sand $(20 \mathrm{~g})$ filled the cylinder vial; atop it, a layer of glass wool and quartz sand (15 g) were added to prevent the soil sample from splashing. Both the glass wool and quartz sand were pretreated with acid. The soil samples $(n=3)$ were adjusted to $60 \%$ of field water capacity [35], sealed, and incubated at $35^{\circ} \mathrm{C}$ in an LRH-80 incubator (Juchuang Co., Ltd., Qingdao, China). At days 0, 7, 14, 21, 28, 42, and 56, the soil samples were leached with $100 \mathrm{~mL}$ of $0.01 \mathrm{M} \mathrm{CaCl}_{2}$; this was done four times, followed with $20 \mathrm{~mL}$ of a nutrient solution devoid of $\mathrm{N}\left(0.002 \mathrm{M} \mathrm{CaSO}_{4} \cdot 2 \mathrm{H}_{2} \mathrm{O} ; 0.002 \mathrm{M} \mathrm{MgSO}_{4} ; 0.005 \mathrm{M} \mathrm{Ca}\left(\mathrm{H}_{2} \mathrm{PO}_{4}\right)_{2} \cdot \mathrm{H}_{2} \mathrm{O}\right.$; $0.0025 \mathrm{M} \mathrm{K}_{2} \mathrm{SO}_{4}$ ). After the leaching, the excess water was removed under $8 \mathrm{kPa}$ negative pressure; all the leachate was collected for the determination of $\mathrm{NH}_{4}{ }^{+}-\mathrm{N}$ and $\mathrm{NO}_{3}{ }^{-}-\mathrm{N}$.

Table 1. Basic chemical properties of soils at the paddy field, $P$. plantation without mulching and $P$. plantation with mulching sites.

\begin{tabular}{|c|c|c|c|c|c|c|}
\hline Site Treatment & $\mathrm{pH}$ & $\begin{array}{c}\text { SOM } \\
\mathrm{g} \mathrm{kg}^{-1}\end{array}$ & $\begin{array}{c}\text { TN } \\
\mathrm{g} \mathrm{kg}^{-1}\end{array}$ & $\begin{array}{l}\mathrm{NO}_{3}{ }^{--N} \\
\mathrm{mg} \mathrm{kg}^{-1}\end{array}$ & $\begin{array}{l}\mathrm{NH}_{4}{ }^{+}-\mathrm{N} \\
\mathrm{mg} \mathrm{kg}^{-1}\end{array}$ & $\begin{array}{c}\mathrm{C} / \mathrm{N} \\
\text { Ratio }\end{array}$ \\
\hline PS & $6.54 \pm 0.18 \mathrm{a}$ & $43.26 \pm 3.47 \mathrm{a}$ & $2.59 \pm 0.11 \mathrm{a}$ & $6.18 \pm 1.78 c$ & $8.67 \pm 0.51 c$ & $9.69 \pm 0.78 \mathrm{ab}$ \\
\hline PNM & $4.75 \pm 0.11 b$ & $34.16 \pm 0.54 c$ & $2.08 \pm 0.04 b$ & $23.85 \pm 1.56 \mathrm{~b}$ & $12.72 \pm 1.26 \mathrm{~b}$ & $9.53 \pm 0.15 b$ \\
\hline PM & $4.00 \pm 0.04 c$ & $36.58 \pm 0.52 b$ & $2.08 \pm 0.12 b$ & $43.32 \pm 3.37 \mathrm{a}$ & $20.22 \pm 1.11 \mathrm{a}$ & $10.20 \pm 0.15 a$ \\
\hline
\end{tabular}

PS, paddy soil; PNM, Phyllostachys praecox plantation without mulching; PM, P. praecox plantation with mulching. SOM, soil organic matter; $\mathrm{TN}$, soil total nitrogen; $\mathrm{NH}_{4}{ }^{+}-\mathrm{N}$, ammonium $\mathrm{N} ; \mathrm{NO}_{3}{ }^{-}-\mathrm{N}$, nitrate N. Different lower-case letters indicate significant differences among the treatments.

\subsection{Soil Organic Nitrogen Fractionation}

Forms of soil organic $\mathrm{N}$ were identified from the hydrolysate prepared by refluxing the soil with $6 \mathrm{M} \mathrm{HCl}$ in a $120{ }^{\circ} \mathrm{C}$ oil bath, for $12 \mathrm{~h}$ [36]. The different soil organic $\mathrm{N}$ fractionations were measured according to Wang et al. [37]. Total hydrolyzable N (THN) was determined by steam distillation with $10 \mathrm{M} \mathrm{NaOH}$ after the Kjeldahl digestion of the acid hydrolysate. Nonhydrolyzable N (NHN) was calculated as follows:

$$
\mathrm{NHN}=\text { Total } \mathrm{N}-\mathrm{THN}
$$

Hydrolyzable ammonium $\mathrm{N}$ (AN) was measured by steam distillation with $3.5 \%(w / v)$ $\mathrm{MgO}$. Amino sugar N (ASN) was calculated as the difference between the AN value and that obtained from steam distillation of the hydrolysate with a phosphate-borate buffer at $\mathrm{pH}=11.2$. Amino acid $\mathrm{N}$ (AAN) was also determined by steam distillation. This was with an aliquot of the hydrolysate with a phosphate-borate buffer and $5 \mathrm{M} \mathrm{NaOH}$, after heating the $0.5 \mathrm{M} \mathrm{NaOH}$ at $100{ }^{\circ} \mathrm{C}$ to decompose the hexosamines and remove $\mathrm{NH}_{3}-\mathrm{N}$; with ninhydrin powder added to convert the amino- $\mathrm{N}$ to $\mathrm{NH}_{3}-\mathrm{N}$. The amount of unknown hydrolyzable $\mathrm{N}$ (UHN) was calculated as follows:

$$
\mathrm{UHN}=\mathrm{THN}-(\mathrm{AN}+\mathrm{ASN}+\mathrm{AAN})
$$

\subsection{Models of Nitrogen Mineralization Kinetics}

Four models may be used to fit $\mathrm{N}_{\min }$ kinetics according to Li et al. [38]. There is the effective accumulated temperature model:

$$
Y=k\left(\left(T-T_{0}\right) D\right)^{n}
$$

where, $Y$ is the cumulative amount of $\mathrm{N}$ mineralized $\left(\mathrm{mg} \mathrm{N} \mathrm{kg}^{-1}\right), T_{0}$ is set to $15^{\circ} \mathrm{C}$ [39], $T$ is the incubation temperature, $D$ is the incubation time in days, while $k$ and $n$ are the mineralization constants.

The single first-order exponential model ('one-pool model') has this form:

$$
N_{t}=N_{0}\left(1-e^{-k_{0} t}\right)
$$


where, $N_{t}$ is the cumulative amount of $\mathrm{N}$ mineralized over time $t\left(\mathrm{mg} \mathrm{N} \mathrm{kg}^{-1}\right), N_{0}$ denotes the potentially mineralizable $\mathrm{N}$, while $k_{0}$ is the first-order rate coefficient [34].

The double first-order exponential model ('two-pool model') has this form:

$$
N_{t}=N_{a}\left(1-e^{-k_{a} t}\right)+N_{r}\left(1-e^{-k r t}\right)
$$

where, $N_{a}$ and $k_{a}$ represent the $\mathrm{N}$ potential and the first-order rate coefficient of the readily available fraction, respectively; the $N_{r}$ and $k_{r}$ are the corresponding $\mathrm{N}$ potential and the first-order rate coefficient of the resistant matter fraction, respectively [40].

Finally, the mixed first- and zero-order model ('special model') has this form:

$$
N_{t}=N_{a 0}\left(1-e^{-k_{a 0} t}\right)+C_{r} t
$$

where, $C_{r}$ is the constant decomposition rate of the resistant matter fraction, while both $N_{a 0}$ and $k_{a 0}$ terms are the same as those defined for the two-pool model just above [41].

\subsection{Data Analysis}

The data were calculated and plotted using Origin 2019 software (OriginLab, Northampton, MA, USA). Each response variable was subjected to a one-way ANOVA (analysis of variance) using IBM SPSS Statistics 20.0 (SPSS Inc., Chicago, IL, USA); differences between the three site treatments were evaluated by Duncan's multiple range test at a significance level of 0.05 . Before the statistical analysis, the obtained data was validated and fitted for normal distribution. Using nonlinear regression, the mineralization parameters were estimated from the cumulative amounts of extracted $\mathrm{NH}_{4}{ }^{+}$and $\mathrm{NO}_{3}{ }^{-}$over the incubation time, this was done separately for all four models. The linear correlation between two variables was determined by Pearson's $r$ coefficient. A 999-permutation Mantel test was used to test the relationships among soil properties and soil cumulative mineralized $\mathrm{N}$, and performed using the "Vegan" packages in R v 4.0.2 (R Foundation for Statistical Computing, Vienna, Austria).

\section{Results}

\subsection{Basic Soil Properties of Bamboo Plantations}

As Table 1 shows, the $\mathrm{pH}$ of the surface layer soil $(0-20 \mathrm{~cm})$ in the PS was decreased significantly after initial conversion to the P. praecox bamboo plantation $(p<0.05)$, and the mulching significantly decreased the $\mathrm{pH}$ of PNM by $15.79 \%(p<0.05)$. Similarly, the SOM content decreased significantly after conversion from paddy field to bamboo plantation $(p<0.05)$, but the mulching significantly increased the SOM content of PNM by $7.08 \%$ $(p<0.05)$. The TN content ranged from 2.08 to $2.59 \mathrm{~g} \mathrm{~kg}^{-1}$ among all three treatment sites, being significantly higher in the PS than the two established bamboo plantations $(p<0.05)$. Although the $\mathrm{NO}_{3}{ }^{-}-\mathrm{N}$ and $\mathrm{NH}_{4}{ }^{+}-\mathrm{N}$ contents were increased after mulching, the highest content of $\mathrm{NO}_{3}{ }^{-}-\mathrm{N}$ and $\mathrm{NH}_{4}{ }^{+}-\mathrm{N}$ was observed in the PM, not the PNM treatment. In addition, $\mathrm{NH}_{4}{ }^{+}-\mathrm{N}$ accounted for the majority of mineralized $\mathrm{N}$ at PS, while the mineralized $\mathrm{N}$ was dominated by $\mathrm{NO}_{3}{ }^{-}-\mathrm{N}$ at the two P. praecox plantations. The $\mathrm{C} / \mathrm{N}$ ratio ranged from 9.53 to 10.20 among the three treatments.

\subsection{Soil Organic Nitrogen Fractions}

The soil THN of PS, PNM, and PM site treatments accounted for $74.90 \%, 75.72 \%$, and $75.11 \%$ of the TN content, respectively. The THN content ranged from 1564 to $1940 \mathrm{mg} \mathrm{kg}^{-1}$ (Figure 1), and it was significantly higher in the PS than P. praecox soils $(p<0.05)$. With mulching applied, the soil THN content decreased whereas the soil NHN content increased, but no significant difference was detected between PNM and PM $(p>0.05)$. The AAN content ranged from 532.1 to $819.6 \mathrm{mg} \mathrm{kg}^{-1}$ among the three site treatments. With conversion of the paddy field to a P. praecox bamboo plantation, the soil's AAN content and proportion decreased significantly $(p<0.05)$, but then slightly increased with mulching applied (Figure $2 \mathrm{~B})$; however, 
the proportion of THN consisting of AAN was similar between PNM and PM (Figure 2A). After establishing the P. praecox plantations, their AN and ASN proportions of THN had both increased significantly $(p<0.05)$, but the AN and ASN contents did not differ significantly between the bamboo plantations. For the UHN content, its ranking was PS $>$ PNM $>$ PM. Across the site treatments, the content of the organic $\mathrm{N}$ fractions had this general ranking: AAN (532-820 $\left.\mathrm{mg} \mathrm{kg}^{-1}\right)>$ AN (434-480 $\left.\mathrm{mg} \mathrm{kg}^{-1}\right) \approx \mathrm{UHN}\left(457-498 \mathrm{mg} \mathrm{kg}^{-1}\right)>$ ASN (147-171 $\left.\mathrm{mg} \mathrm{kg}^{-1}\right)$.

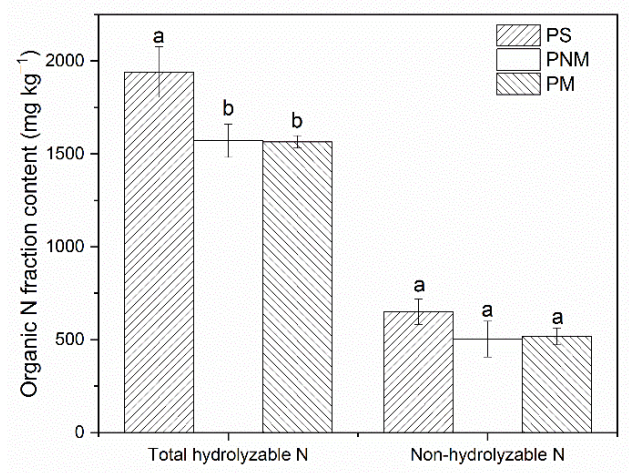

Figure 1. The content of total hydrolyzable $\mathrm{N}$ and nonhydrolyzable $\mathrm{N}$ in soils for the paddy field, $P$. plantation without mulching and $P$. plantation with mulching sites. PS, rice paddy soil; PNM, Phyllostachys praecox plantation without mulching; PM, P. praecox plantation with mulching. Bars are the mean \pm standard error $(n=3)$. Different lower-case letters indicate significant differences according to Duncan's test at the 0.05 level.

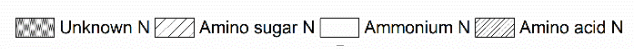
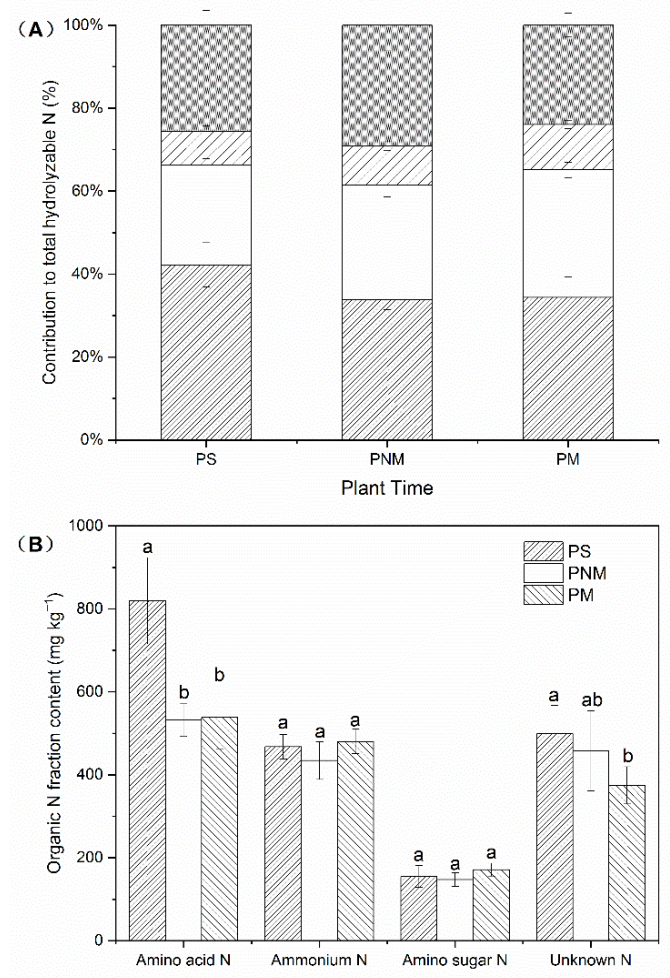

Figure 2. The proportion (A) and content (B) of different organic nitrogen fractions for the paddy field, $P$. plantation without mulching and $P$. plantation with mulching sites. PS, rice paddy soil; PNM, Phyllostachys praecox plantation without mulching; PM, P. praecox plantation with mulching. Bars are the mean \pm standard error $(n=3)$. Different lower-case letters indicate significant differences according to Duncan's test at the 0.05 level. 


\subsection{Soil Nitrogen Mineralization}

As Figure 3 shows, the total amount of $\mathrm{N}$ mineralized during the 56-day incubation varied significantly among the different treatments $(p<0.05)$, being greatest in PS at $191.1 \mathrm{mg} \mathrm{kg}^{-1}$, while the mineralized N of PNM and PM amounted to 128.8 and $95.48 \mathrm{mg} \mathrm{kg}^{-1}$, respectively. Similarly, the soil $\mathrm{N}_{\min }$ rate decreased significantly after converting the paddy field to a P. praecox bamboo plantation $(p<0.05)$, being significantly reduced by mulching as well $(p<0.05)$. Furthermore, the process of $\mathrm{N}_{\min }$ mainly happened during the first 2 weeks and declined with time, and by day 21 of the incubation period a higher mineralization rate characterized the PNM. Across all treatments, the mineralized $\mathrm{N}$ of the first 2 weeks $\left(\mathrm{N}_{14}\right)$ ranged from 52.51 to $138.0 \mathrm{mg} \mathrm{kg}^{-1}$ and the ratio of $\mathrm{N}_{14}$ to $\mathrm{N}_{\mathrm{t}}$ (total mineralized $\mathrm{N}$ ) during the incubation period fell by $49.76 \%-72.25 \%$ (Table 2 ). The cumulative mineralized $\mathrm{N}$ was mainly dominated by $\mathrm{NH}_{4}{ }^{+}-\mathrm{N}$, in that it accounted for $85.47 \%, 72.78 \%$, and $75.87 \%$ of the total mineralized N in PS, PNM, and PM, respectively.

(A)

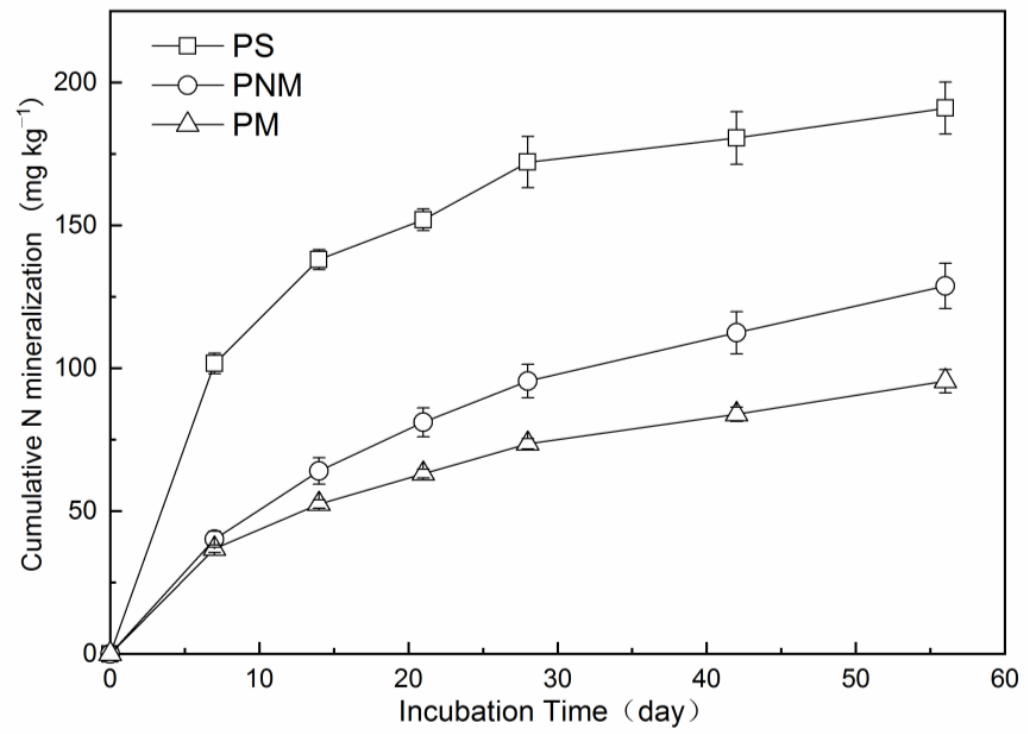

(B)

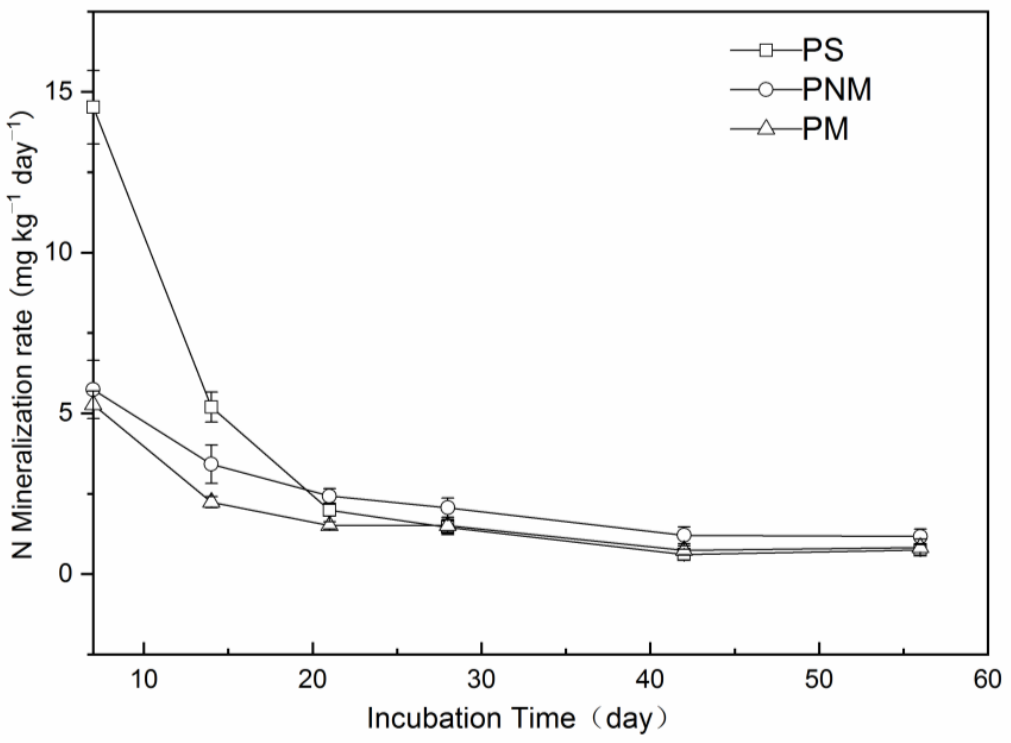

Figure 3. The cumulative nitrogen mineralization (A) and mineralization rate (B) for the paddy field, $P$. plantation without mulching and $P$. plantation with mulching sites. PS, rice paddy soil; PNM, Phyllostachys praecox plantation without mulching; PM, P. praecox plantation with mulching. Bars are the mean \pm standard error $(n=3)$. 
Table 2. The $\mathrm{N}$ mineralization for the paddy field, $P$. plantation without mulching and $P$. plantation with mulching sites.

\begin{tabular}{|c|c|c|c|c|c|c|c|c|c|}
\hline Treatment & $\begin{array}{l}\mathrm{NH}_{4}{ }^{+}-\mathrm{N} \\
\mathrm{mg} \mathrm{kg}^{-1}\end{array}$ & $\begin{array}{l}\text { 14 Days } \\
\mathrm{NO}_{3}-\mathrm{-N} \\
\mathrm{mg} \mathrm{kg}^{-1}\end{array}$ & $\begin{array}{c}\mathrm{N}_{14} \\
\mathrm{mg} \mathrm{kg}^{-1}\end{array}$ & $\begin{array}{l}\mathrm{NH}_{4}{ }^{+}-\mathrm{N} \\
\mathrm{mg} \mathrm{kg}^{-1}\end{array}$ & $\begin{array}{l}56 \text { Days } \\
\mathrm{NO}_{3}-\mathrm{-N} \\
\mathrm{mg} \mathrm{kg}^{-1}\end{array}$ & $\begin{array}{c}\mathrm{N}_{\mathrm{t}} \\
\mathrm{mg} \mathrm{kg}^{-1}\end{array}$ & $\begin{array}{c}\mathrm{N}_{14} \mathrm{~N}_{\mathrm{t}}{ }^{-1} \\
\%\end{array}$ & $\begin{array}{c}\mathrm{N}_{14} \mathrm{TN}^{-1} \\
\%\end{array}$ & $\begin{array}{c}\mathrm{N}_{\mathrm{t}} \mathrm{TN}^{-1} \\
\% \\
\%\end{array}$ \\
\hline PS & $117.03 \pm 3.20 \mathrm{a}$ & $21.00 \pm 2.18 \mathrm{a}$ & $138.04 \pm 3.51 \mathrm{a}$ & $163.30 \pm 7.09 \mathrm{a}$ & $27.76 \pm 2.24 \mathrm{ab}$ & $191.06 \pm 9.10 \mathrm{a}$ & 72.25 & 5.33 & 7.38 \\
\hline PNM & $43.79 \pm 0.84 b$ & $20.30 \pm 5.04 a$ & $64.09 \pm 4.65 \mathrm{~b}$ & $93.73 \pm 1.97 b$ & $35.06 \pm 8.19 a$ & $128.79 \pm 7.89 b$ & 49.76 & 3.08 & 6.19 \\
\hline PM & $38.90 \pm 0.97 \mathrm{~b}$ & $13.61 \pm 1.64 b$ & $52.51 \pm 1.48 \mathrm{~b}$ & $72.44 \pm 1.97 c$ & $23.04 \pm 2.61 \mathrm{~b}$ & $95.48 \pm 4.10 c$ & 55.00 & 2.52 & 4.59 \\
\hline
\end{tabular}

$\mathrm{N}_{14}$, the cumulative nitrogen mineralization at the 14 th day of incubation; $\mathrm{N}_{\mathrm{t}}$, the cumulative nitrogen mineralization at the end of the incubation period. Different lower-case letters indicate significant differences among the treatments.

\subsection{Model Fitting of N Mineralization Kinetics}

As seen in Figure 4, the effective accumulated temperature, one-pool, two-pool, and special models, all provided a very good fit to the data according to their $R^{2}\left(R^{2}\right.$-values: $\left.0.989-1.000\right)$, and their estimated model parameters are listed in Table 3. In the effective accumulated temperature model, the $k$ value (i.e., the mineralization capacity) of the paddy field significantly exceeded that of either $P$. praecox plantation, which matched the trend in the variation of cumulative $\mathrm{N}_{\min }$. In the one-pool model, the $N_{0}$ value surpassed its $\mathrm{N}_{t}$ (Table 2) in the PNM and PM, but not in the PS treatment, and the trend in the variation of $N_{0}$ (i.e., potentially mineralizable $\mathrm{N}$ ) was on par with $\mathrm{N}_{\mathrm{t}}$ among all the treatments; the $k_{0}$ values ranged from 0.044 to $0.1 \mathrm{~d}^{-1}$. In the two-pool model, the value of $N_{a}$ (i.e., $\mathrm{N}$ potential of the readily available fraction) was significantly higher than that of $N_{r}$ (i.e., $\mathrm{N}$ potential of the resistant matter fraction). In the special model, the $N_{a 0}$ values ranged almost threefold, from 50.44 to $146.1 \mathrm{mg} \mathrm{kg}^{-1}$, and their pattern resembled that found for $N_{a}$ in the twopool model; indeed, the special model gave a similarly good fit to empirical data as the two-pool model.

\subsection{Relationship between N Mineralization Kinetics Parameters with Soil Properties}

The obtained correlation coefficients between the $\mathrm{N}_{\text {min }}$ kinetics parameters and SOM, soil TN, $\mathrm{NH}_{4}{ }^{+}-\mathrm{N}, \mathrm{NO}_{3}{ }^{-}-\mathrm{N}$, and organic $\mathrm{N}$ fractions are shown in Table 4. Significant correlations emerged between the cumulative mineralized $\mathrm{N}$ and most of the indicators assessed. In particular, the $N_{0}, N_{a}$, and $N_{a 0}$ were correlated with many indicators, while relatively few indicators were significantly correlated with the mineralization potential parameters $N_{r}$ and $C_{r}$, and the rate constants $\left(k_{0}, k_{a}, k_{r}, k_{a 0}\right)$. Soil pH, SOM, TN, THN, and AAN were each significantly and positively correlated with $\mathrm{N}_{t}$ and the mineralization potential, whereas they were poorly correlated with the mineralization potential parameters $N_{r}$ and $C_{r}$ of the resistant matter fraction. Both $\mathrm{NH}_{4}{ }^{+}-\mathrm{N}$ and $\mathrm{NO}_{3}{ }^{-}-\mathrm{N}$ had significant negative correlations with $\mathrm{N}_{\mathrm{t}}$ and the mineralization potential; by contrast, $\mathrm{ASN}, \mathrm{AN}$, and NHN had relatively little influence on the soil $\mathrm{N}_{\text {min }}$ parameter.

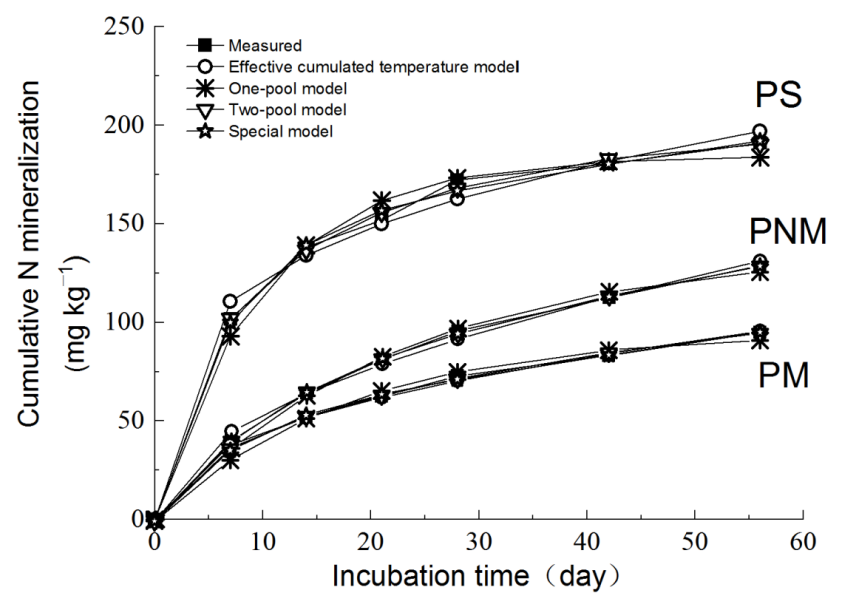

Figure 4. The cumulative nitrogen mineralization for the paddy field, $P$. plantation without mulching and P. plantation with mulching sites. PS, rice paddy soil; PNM, Phyllostachys praecox plantation without mulching; PM, P. praecox plantation with mulching. Bars are the mean \pm standard error $(n=3)$. 
Table 3. Estimated parameters of four different models and their goodness-of-fit $\left(\mathrm{R}^{2}\right)$ obtained from nonlinear regressions.

\begin{tabular}{|c|c|c|c|c|c|}
\hline Model Name & Parameter & Unit & PS & PNM & PM \\
\hline \multirow{3}{*}{ Effective cumulated temperature model } & $\mathrm{R}^{2}$ & & 0.991 & 0.996 & 0.998 \\
\hline & $k$ & & 28.01 & 3.468 & 4.421 \\
\hline & $n$ & & 0.278 & 0.517 & 0.439 \\
\hline \multirow{3}{*}{ One-pool model } & $\mathrm{R}^{2}$ & & 0.991 & 0.996 & 0.989 \\
\hline & $N_{0}$ & $\mathrm{mg} \mathrm{kg}^{-1}$ & 184.4 & 137.5 & 95.76 \\
\hline & $k_{0}$ & $d^{-1}$ & 0.100 & 0.044 & 0.056 \\
\hline \multirow{6}{*}{ Two-pool model } & $R^{2}$ & & 0.999 & 1.000 & 0.999 \\
\hline & $N_{a}+N_{r}$ & $\mathrm{mg} \mathrm{kg}^{-1}$ & 197.7 & 255.3 & 124.3 \\
\hline & $N_{a}$ & $\mathrm{mg} \mathrm{kg}^{-1}$ & 79.97 & 61.01 & 31.05 \\
\hline & $k_{a}$ & $\mathrm{~d}^{-1}$ & 0.265 & 0.095 & 0.213 \\
\hline & $N_{r}$ & $\mathrm{mg} \mathrm{kg}^{-1}$ & 117.7 & 194.2 & 93.22 \\
\hline & $k_{r}$ & $\mathrm{~d}^{-1}$ & 0.049 & 0.008 & 0.021 \\
\hline \multirow{4}{*}{ Special model } & $R^{2}$ & & 0.998 & 1.000 & 0.999 \\
\hline & $N_{a 0}$ & $\mathrm{mg} \mathrm{kg}^{-1}$ & 146.1 & 72.94 & 50.44 \\
\hline & $k_{a 0}$ & $\mathrm{~d}^{-1}$ & 0.148 & 0.085 & 0.131 \\
\hline & $C_{r}$ & $\mathrm{mg} \mathrm{kg}^{-1} \mathrm{~d}^{-1}$ & 0.821 & 1.006 & 0.808 \\
\hline
\end{tabular}

PS, rice paddy soil; PNM, Phyllostachys praecox plantation without mulching; PM, P. praecox plantation with mulching.

Table 4. Pearson correlations between the mineral-N, parameters in the fitted models, and soil properties.

\begin{tabular}{|c|c|c|c|c|c|c|c|c|c|c|c|c|}
\hline $\begin{array}{c}\text { Soil } \\
\text { Properties }\end{array}$ & $N_{t}$ & $k$ & $n$ & $N_{0}$ & $k_{0}$ & $N_{a}$ & $k_{a}$ & $N_{r}$ & $k_{r}$ & $N_{a 0}$ & $k_{a 0}$ & $C_{r}$ \\
\hline SOM & $0.713^{* *}$ & $0.757^{* *}$ & $-0.764^{* *}$ & $0.603^{* *}$ & $0.765^{* *}$ & $0.485^{*}$ & $0.658^{* *}$ & & $0.770^{* *}$ & $0.685^{* *}$ & $0.639 * *$ & \\
\hline TN & $0.798^{* *}$ & 0.863 ** & $-0.843^{* *}$ & $0.729^{* *}$ & $0.858^{* *}$ & $0.625^{* *}$ & $0.658^{* *}$ & & 0.847 ** & 0.810 ** & $0.629^{* *}$ & $-0.409 *$ \\
\hline $\mathrm{NH}_{4}{ }^{+}-\mathrm{N}$ & -0.722 ** & $0.637^{* *}$ & 0.463 * & $-0.798^{* *}$ & $-0.539 * *$ & -0.753 ** & -0.144 & & -0.475 * & $-0.725^{* *}$ & & \\
\hline $\mathrm{NO}_{3}{ }^{-}-\mathrm{N}$ & $-0.677^{* *}$ & $-0.671^{* *}$ & $0.541^{* *}$ & $-0.755^{* *}$ & $-0.597^{* *}$ & $-0.680^{* *}$ & -0.288 & & $-0.553^{* *}$ & $-0.716^{* *}$ & & \\
\hline $\mathrm{pH}$ & $0.906^{* *}$ & $0.946^{* *}$ & $-0.819^{* *}$ & $0.968^{* *}$ & $0.884 * *$ & 0.912 ** & $0.446^{*}$ & & 0.823 ** & $0.984^{* *}$ & & \\
\hline AAN & $0.744^{* *}$ & $0.832^{* *}$ & $-0.806^{* *}$ & $0.714^{* *}$ & 0.825 ** & $0.624 * *$ & $0.609^{* *}$ & $-0.436 *$ & $0.810^{* *}$ & $0.789^{* *}$ & $0.578^{* *}$ & $-0.407^{*}$ \\
\hline AN & & & & & & & $0.458 *$ & $0.568^{* *}$ & & & $0.477^{*}$ & -0.413 * \\
\hline UHN & $\begin{array}{l}0.440 * \\
0.449 *\end{array}$ & $0.475^{*}$ & & $0.609^{* *}$ & & $0.617^{* *}$ & & & & $0.561^{* *}$ & & \\
\hline THN & $0.718^{* *}$ & $0.860^{* *}$ & $-0.827^{* *}$ & $0.747^{* *}$ & 0.849 ** & 0.653 ** & $0.619^{* *}$ & & 0.831 ** & $0.819^{* *}$ & $0.587^{* *}$ & 0.393 \\
\hline
\end{tabular}

$\mathrm{SOM}$, soil organic matter; $\mathrm{TN}$, soil total nitrogen; $\mathrm{NH}_{4}{ }^{+}-\mathrm{N}$, ammonium $\mathrm{N} ; \mathrm{NO}_{3}{ }^{-}-\mathrm{N}$, nitrate $\mathrm{N}$; THN, hydrolyzable $\mathrm{N}$; $\mathrm{AN}$, ammonium $\mathrm{N}$; AAN, amino acid N; ASN, amino sugar N; UHN, unknown hydrolyzable $\mathrm{N} ; \mathrm{NHN}$, nonhydrolyzable $\mathrm{N}$. The * and ${ }^{* *}$ denote significance at $p<0.05$ and $p<0.01$, respectively. The blanks in the form indicate there is no significant correlation between the two parameters.

As revealed by the Mantel test (Table 5), the soil $\mathrm{pH}$ value, SOM, soil AAN content, $\mathrm{TN}, \mathrm{NH}_{4}{ }^{+}-\mathrm{N}$, and $\mathrm{NO}_{3}{ }^{-}-\mathrm{N}$ content exerted a significant impact on soil cumulative mineralized $\mathrm{N}$, wherein $\mathrm{TN}(\mathrm{r}=0.9839, p=0.001), \mathrm{NH}_{4}{ }^{+}-\mathrm{N}(\mathrm{r}=0.9720, p=0.001)$, and the $\mathrm{pH}$ value $(\mathrm{r}=0.9549, p=0.001)$ were the primary drivers.

Table 5. Significance tests of the relationship between soil properties and soil cumulative mineralized $\mathrm{N}$ based on the Mantel test.

\begin{tabular}{ccc}
\hline & $\mathbf{r}$ & $p$ \\
\hline $\mathrm{SOM}$ & 0.5219 & 0.011 \\
$\mathrm{TN}$ & 0.9839 & 0.001 \\
$\mathrm{NH}_{4}^{+}-\mathrm{N}$ & 0.9720 & 0.001 \\
$\mathrm{NO}_{3}^{-}-\mathrm{N}$ & 0.8338 & 0.002 \\
$\mathrm{pH}$ & 0.9549 & 0.001 \\
$\mathrm{AN}$ & -0.1961 & 0.889 \\
$\mathrm{AAN}$ & 0.6123 & 0.004 \\
$\mathrm{ASN}$ & 0.0055 & 0.392 \\
$\mathrm{UHN}$ & 0.1737 & 0.140 \\
$\mathrm{NHN}$ & 0.2506 & 0.061
\end{tabular}

SOM, soil organic matter; $\mathrm{TN}$, soil total nitrogen; $\mathrm{NH}_{4}{ }^{+} \mathrm{N}$, ammonium $\mathrm{N} ; \mathrm{NO}_{3}{ }^{-}-\mathrm{N}$, nitrate $\mathrm{N}$; $\mathrm{AN}$, ammonium $\mathrm{N}_{\ell}$ AAN, amino acid N; ASN, amino sugar N; UHN, unknown hydrolyzable N; NHN, nonhydrolyzable N. 


\section{Discussion}

It is well known that land-use changes as well as forest management practices can greatly alter the properties of soil $[11,42]$. Our results suggest the conversion from paddy field to P. praecox bamboo plantation could decrease soil $\mathrm{pH}$ considerably, which is consistent with findings reported by Holubík et al. [43]. In addition, the mulching practice further induced soil acidification, likely due to the heavy application of chemical fertilizer and phenolic acids excreted from the decomposition of organic materials in the mulch [28]. It is widely accepted now that land-use change can markedly change SOM content in soils [44]. Our results showed that mulching can increase the SOM in a bamboo plantation, an outcome largely driven by the direct input from organic materials [45]. Nevertheless, the mulched bamboo plantation showed less SOM than the paddy field. This result could be explained in two ways. First, the soil organic carbon (SOC) of bamboo stands with mulching mostly exists in unstable forms that are not conducive to preservation [46,47]. Second, the waterlogging condition in a paddy field generally promotes the preservation and fixation of SOC [48]. The decline of TN in soils of the bamboo without mulching mainly arose from the reduction in fertilization and rapid growth of $P$. praecox. We found that $\mathrm{NH}_{4}{ }^{+}-\mathrm{N}$ made up most of the mineralized $\mathrm{N}$ present in rice paddy soil, which could have resulted from waterlogging that inhibited bacterial nitrification activities, thereby preventing $\mathrm{NH}_{3}$ volatilization and $\mathrm{NO}_{3}{ }^{-}-\mathrm{N}$ denitrification losses. This would have created an environment suitable for soil organic $\mathrm{N}_{\min }$, enabling the accumulation of $\mathrm{NH}_{4}{ }^{+}-\mathrm{N}$ [49]. In stark contrast, the higher proportion of $\mathrm{NO}_{3}{ }^{-}-\mathrm{N}$ present in both $P$. praecox plantations might be linked to their high $\mathrm{N}$ fertilization input and better ventilation $[50,51]$.

Adding organic material can change soil environmental conditions and increase the $\mathrm{N}$ inputs into soil [52], for which the $\mathrm{N}$ forms and fractions are important factors affecting the overall $\mathrm{N}$ availability in soils [53]. In this context, the THN is often classified as labile soil organic N while the NHN is considered as stable organic N [54]; our study revealed the sensitivity of labile fractions of soil to land-use change (from a paddy field to a bamboo plantation). The AAN accounted for $25.64 \%-31.66 \%$ of the TN among different site treatments, a result consistent with Stevenson [55], who found AAN comprised approximately $20 \%-30 \%$ of the soil TN. Free amino acids can be absorbed by plants and assimilated directly by soil microorganisms [56,57], so mulching had a negligible impact on the AAN content. However, AN and ASN are more labile than the other two fractions of hydrolyzable soil N, and both play vital roles in the mineralization process [58,59]. Mulching led to a marked improvement in the AN and ASN contents, but still, the stable fractions accumulated to a higher level than did the labile $\mathrm{N}$ fraction in the mulched bamboo plantation (Figure 1). A plausible reason for why that happened, is that the mineralization rate of NHN was too low, which would have driven an accumulation in soil. Furthermore, the low soil $\mathrm{pH}$ of P. praecox likely augmented the soil exchangeable aluminum (Al) and organic complexed $\mathrm{Al}$, which would have contributed to the accumulation of stable organic N [60]. In general, increasing the soil organic $\mathrm{N}$ content will necessarily influence aspects of soil $\mathrm{N}$ cycling to some extent, namely the mineralization rate [61]. However, due to the higher accumulation of NHN, the effects of mulching on $\mathrm{N}_{\min }$ could be rather complicated.

Soil organic $\mathrm{N}$ is ammonified by soil microbes into $\mathrm{NH}_{4}{ }^{+}-\mathrm{N}$, followed by its nitrification. The ensuing $\mathrm{NO}_{3}{ }^{-}-\mathrm{N}$ is more mobile than labile organic $\mathrm{N}$ forms such as AAN, which can easily diffuse into the rhizosphere and is available for plant uptake $[62,63]$. Accordingly, soil $\mathrm{N}_{\min }$ is the main index of the $\mathrm{N}$ supply capacity of soil. Nonetheless, the application of organic materials in excessive amounts onto soil could strongly affect its $\mathrm{N}$ cycling dynamics [64,65]. In our study, the paddy field had a significantly higher mineralization rate and mineralized amount than did the two bamboo plantations. Perhaps this was because the paddy field had a more suitable $\mathrm{pH}$ - since the optimum soil $\mathrm{pH}$ for ammonification reportedly ranges from about $\mathrm{pH} 6.0$ to 8.0 [66], and the highest TN content was also observed in the paddy field, according to the Mantel test, so TN, $\mathrm{NH}_{4}{ }^{+}-\mathrm{N}$ and $\mathrm{pH}$ were the key factors influencing the soil cumulative mineralized $\mathrm{N}$ (Table 5). The lowest ratio of $\mathrm{N}_{\mathrm{t}} / \mathrm{TN}$ was observed in the PM (Table 2), which indicated the organic 
material mulching diminished the capacity for soil mineralization, for which $\mathrm{N}_{\mathrm{t}}$ and $\mathrm{pH}$ were evidently positively correlated (Table 4). Moreover, soil $\mathrm{pH}$ plays a key role in modulating the relative abundance and diversity of belowground bacterial communities [67]. Chen et al. [68] reported that soil bacterial diversity and soil urease activity decreased after multiple times of mulching of a P. praecox plantation, and they went on to predict a lower functional diversity of soil bacterial microbiomes related to the cycling of amino acids and carbohydrates after long-term mulching. Therefore, we believe mulching slightly increased the labile soil organic $\mathrm{N}$, but because the diversity of soil microorganisms was reduced, the stable organic $\mathrm{N}$ pool increased, resulting in the low $\mathrm{N}_{\min }$ of P. praecox plantations (Figure 3). Our study highlights that soil $\mathrm{N}_{\min }$ is restricted by soil $\mathrm{pH}$. Under low $\mathrm{pH}$ conditions, the enhancement from fertilization and organic matter fails to increase the soil $\mathrm{N}_{\text {min }}$ capacity and this could reduce the $\mathrm{N}$-use efficiency.

It is widely accepted that $\mathrm{N}_{\min }$ reactions generally follow first-order kinetics [69]. According to the $k$ value (the mineralization capacity, Table 3 ), the effective cumulated temperature model yielded a sound prediction for the paddy field, but neither the $k$ nor $n$ value can be used to directly calculate the potential of $\mathrm{N}_{\min }$ [38]. Although both $k$ and $n$ values did show good correlations with soil properties and organic $\mathrm{N}$ fractions, the effective cumulated temperature model seemed ill suited for the P. praecox plantation. In the fitted one-pool model, the value for the mineralization potential $N_{0}$ was significantly correlated with the soil properties and THN, which may convey the maximal potential of soil $\mathrm{N}_{\min }$. Yet the $N_{0}$ value was about $96.33 \%$ of the experimental data $\left(\mathrm{N}_{\mathrm{t}}\right)$, and over time the $N_{0}$ value should surpass the observed mineral N. Our results agree with Li et al. [70], who suggested the one-pool model was not suitable for predicting the mineralization potential of rice paddy soil. In earlier work, Serna and Pomares [71] developed the parameter $N_{0} \times k_{0}$ to convey the soil $\mathrm{N}$ supply capacity; here, the $N_{0} \times k_{0}$ values of PS, PNM, and PM respectively were $18.48,6.01,5.34$, and $5.55 \mathrm{mg} \mathrm{kg}^{-1} \mathrm{~d}^{-1}$, hence, these can better indicate the $\mathrm{N}$ supply capacity of the different site treatments. Based on their goodnessof-fit ( $R^{2}$ values) the two-pool and special models outperformed the other two models. Crucially, the two-pool model and special model each divide the soil mineralizable organic $\mathrm{N}$ into two realistic parts: the readily available $\mathrm{N}$ pools and resistant-matter (i.e., slowly decomposing) $\mathrm{N}$ pools [72]. In the two-pool model the mineralization capacity and rate of the two types of N pools are different, and, unlike the two-pool model, in the special model the mineralization amount of slowly decomposing $\mathrm{N}$ pools is linearly correlated with the incubation time. Based on our results for the fitted two-pool model, the size of readily available $\mathrm{N}$ pools across the three site treatments was significantly lower than that of their slowly decomposing $\mathrm{N}$ pools, which suggested the latter had a greater impact on the total mineralization potential. However, $N_{r}$ featured the worst correlations with soil properties and organic $\mathrm{N}$ fractions. Our results support the recent findings of Zhang et al. [73], who argued the special model's $N_{a 0}$ parameter could be used as an index to evaluate the soil $\mathrm{N}$ supply capacity. Both $k_{a 0}$ and $C_{r}$ were also weakly correlated with soil properties and organic $\mathrm{N}$ fractions in the special model. To sum up, all four models gave respectable fits to the data, but the kinetics of $\mathrm{N}_{\min }$ were described more accurately by the two-pool model or special model.

Confirming our hypothesis, the conversion from paddy field to P. praecox bamboo plantation can lead to soil acidification and reductions in soil nutrients, the THN and NHN contents, and soil $\mathrm{N}$ mineralization as well. The practice of mulching further lowered the soil $\mathrm{pH}$ and raised the NHN content, which inhibited both the rate and capacity of soil $\mathrm{N}_{\text {min }}$. Hence, a suitable $\mathrm{pH}$ seems to be crucial for sustaining the long-term soil $\mathrm{N}$ supply in bamboo plantations and bamboo management.

In this study, we are aware of the limitation between the laboratory incubation for $\mathrm{N}$ mineralization and an in situ incubation for $\mathrm{N}_{\min }$. Furthermore, the risk of $\mathrm{N}$ leaching is substantial given the heavy on-site fertilization, low soil $\mathrm{TN}$ and high soil $\mathrm{NO}_{3}{ }^{-}-\mathrm{N}$ content under the mulched P. praecox bamboo plantation. This aspect deserves further attention, 
and we recommend that future in situ research investigate soil $\mathrm{N}$ transformations under mulching conditions to mitigate that potential environmental risk.

\section{Conclusions}

Our results indicated the conversion from rice paddy field to P. praecox plantation could significantly decrease the soil's pH value, as well as its TN and SOM content. Landuse change significantly decreased the THN and NHN, and later mulching reduced the THN yet increased the NHN content. The cumulative mineralized $\mathrm{N}$ and $\mathrm{N}_{\min }$ rate ranked as follows: PS > PNM > PM. Further, $\mathrm{N}_{\min }$ mainly occurred within the initial 2 weeks of incubation and then declined over time. The mineralized $\mathrm{N}$ was dominated primarily by $\mathrm{NH}_{4}{ }^{+}-\mathrm{N}$ rather than $\mathrm{NO}_{3}{ }^{-}-\mathrm{N}$. Although all four kinetics models could be fitted well to the experimental data of $\mathrm{N}_{\min }$, the two-pool and special models best described its kinetics. Our works revealed that soil $\mathrm{pH}$ value, SOM, TN, THN, and AAN were all significantly positively correlated with the cumulative mineralized $\mathrm{N}$ and mineralization potential, but vice versa for $\mathrm{NH}_{4}{ }^{+}-\mathrm{N}$ and $\mathrm{NO}_{3}{ }^{-}-\mathrm{N}$. Besides, the Mantel test suggested that TN, $\mathrm{NH}_{4}{ }^{+}-\mathrm{N}$, and the $\mathrm{pH}$ value were the primary drivers of cumulative mineralized $\mathrm{N}$. Taken together, we may infer that soil $\mathrm{pH}$ exerted the greatest impact on soil $\mathrm{N}_{\min }$ in the mulched bamboo plantation. These findings could foster a better understanding of $\mathrm{N}$ cycling and $\mathrm{N}$ availability under land-use change and mulching conditions, and contribute to developing a scientific basis for the sustainable management of P. praecox plantations not only in China but perhaps elsewhere, too.

Author Contributions: Conceptualization, X.S. and S.Z.; methodology, X.S. and J.G.; software, Z.Q. and J.G.; validation, X.S. and Z.Q.; formal analysis, S.Z. and Z.Q.; investigation, X.S. and S.Z.; resources, S.Z.; data curation, Z.Q.; writing_-Original draft preparation, Z.Q.; writing-Review and editing, X.S., S.Z. and Z.Q.; visualization, Z.Q. and J.G.; supervision, S.Z.; project administration, S.Z.; funding acquisition, S.Z. All authors have read and agreed to the published version of the manuscript.

Funding: We thank the National Key R \& D Project of China (2016FEE001111), the National Natural Science Foundation of China (41671296), and the National Key R \& D Program of China (2016FYE0112700) for financial supports.

Data Availability Statement: The data presented in this study are available on request from the corresponding author.

Conflicts of Interest: The authors declare that they have no competing interests.

\section{References}

1. Li, M.; Zhou, X.; Zhang, Q.; Cheng, X. Consequences of afforestation for soil nitrogen dynamics in central China. Agric. Ecosyst. Environ. 2014, 183, 40-46. [CrossRef]

2. Shan, Z.; Yin, Z.; Yang, H.; Zuo, C.; Zhu, T. Long-Term cultivation of fruit plantations decreases mineralization and nitrification rates in calcareous soil in the Karst Region in Southwestern China. Forests 2020, 11, 1282. [CrossRef]

3. Schulten, H.R.; Schnitzer, M. The chemistry of soil organic nitrogen: A review. Biol. Fertil. Soils 1997, 26, 1-15. [CrossRef]

4. Bremner, J.M. Inorganic forms of nitrogen. In Methods of Soil Analysis; Black, C.A., Ed.; American Society of Agronomy: Madison, WI, USA, 1965; pp. 1179-1237.

5. Stevenson, F.J. Organic Forms of Soil Nitrogen; Nitrogen in Agricultural Soils: Madison, WI, USA, 1982.

6. Burdige, D.J.; Martens, C.S. Biogeochemical cycling in an organic-rich coastal marine basin: 10. The role of amino acids in sedimentary carbon and nitrogen cycling. Geochim. Cosmochim. Acta 1988, 52, 1571-1584. [CrossRef]

7. Jones, D.L.; Kielland, K. Soil amino acid turnover dominates the nitrogen flux in permafrost-dominated taiga forest soils. Soil Biol. Biochem. 2002, 34, 209-219. [CrossRef]

8. Xu, Y.C.; Shen, Q.R.; Ran, W. Content and distribution of forms of organic $\mathrm{N}$ in soil and particle size fractions after long-term fertilization. Chemosphere 2003, 50, 739-745. [CrossRef]

9. Wang, J.; Zhuang, S.; Zhu, Z. Soil organic nitrogen composition and mineralization of paddy soils in a cultivation chronosequence in china. J. Soil Sediment. 2017, 17, 1588-1598. [CrossRef]

10. Zhou, R.; El-Naggar, A.; Li, Y.; Cai, Y.; Chang, S.X. Converting rice husk to biochar reduces bamboo soil $\mathrm{N}_{2} \mathrm{O}$ emissions under different forms and rates of nitrogen additions. Environ. Sci. Pollut. Res. 2021, 28, 28777-28788. [CrossRef] 
11. Haghverdi, K.; Kooch, Y. Soil carbon and nitrogen fractions in response to land use/cover changes. Acta Oecol. $2020,109,103659$. [CrossRef]

12. Veresoglou, S.D.; Sen, R.; Mamolos, A.P.; Veresoglou, D.S. Plant species identity and arbuscular mycorrhizal status modulate potential nitrification rates in nitrogen-limited grassland soils. J. Ecol. 2011, 99, 1339-1349. [CrossRef]

13. Guntiñas, M.E.; Leirós, M.C.; Trasar-Cepeda, C.; Gil-Sotres, F. Effects of moisture and temperature on net soil nitrogen mineralization: A laboratory study. Eur. J. Soil Biol. 2012, 48, 73-80. [CrossRef]

14. Fu, H.; Duan, Y.H.; Zhu, P.; Gao, H.J.; Xu, M.G.; Yang, X.M. Potential N mineralization and availability to maize in black soils in response to soil fertility improvement in Northeast China. J. Soil Sediment. 2021, 21, 905-913. [CrossRef]

15. Neina, D. The role of soil pH in plant nutrition and soil remediation. Appl. Environ. Soil Sci. 2019, 2019, 5794869. [CrossRef]

16. Curtin, D.; Campbell, C.A.; Jalil, A. Effects of acidity on mineralization: pH-dependence of organic matter mineralization in weakly acidic soils. Soil Biol. Biochem. 1998, 30, 57-64. [CrossRef]

17. Feyissa, A.; Yang, F.; Wu, J.; Chen, Q.; Zhang, D.; Cheng, X. Soil nitrogen dynamics at a regional scale along a precipitation gradient in secondary grassland of China. Sci. Total Environ. 2021, 781, 146736. [CrossRef] [PubMed]

18. Zebarth, B.J.; Forge, T.A.; Goyer, C.; Brin, L.D. Effect of soil acidification on nitrification in soil. Can. J. Soil Sci. 2015, 95, 359363. [CrossRef]

19. Cookson, W.R.; Abaye, D.A.; Marschner, P.; Murphy, D.V.; Stockdale, E.A.; Goulding, K.W.T. The contribution of soil organic matter fractions to carbon and nitrogen mineralization and microbial community size and structure. Soil Biol. Biochem. 2005, 37, 1726-1737. [CrossRef]

20. Ros, G.H. Predicting soil N mineralization using organic matter fractions and soil properties: A re-analysis of literature data. Soil Biol. Biochem. 2012, 45, 132-135. [CrossRef]

21. Bechtold, J.S.; Naiman, R.J. Soil texture and nitrogen mineralization potential across a riparian toposequence in a semi-arid savanna. Soil Biol. Biochem. 2006, 38, 1325-1333. [CrossRef]

22. Ollivier, J.; Töwe, S.; Bannert, A.; Hai, B.; Kastl, E.M.; Meyer, A.; Su, M.X.; Kleineidam, K.; Schloter, M. Nitrogen turnover in soil and global change. FEMS Microbiol. Ecol. 2011, 78, 3-16. [CrossRef]

23. Zhang, T.; Li, Y.; Chang, S.X.; Jiang, P.; Zhou, G.; Zhang, J.; Liu, J. Responses of seasonal and diurnal soil $\mathrm{CO}_{2}$ effluxes to land-use change from paddy fields to Lei bamboo (Phyllostachys praecox) stands. Atmos. Environ. 2013, 77, 856-864. [CrossRef]

24. Wu, J.S.; Jiang, P.K.; Chang, S.X.; Xu, Q.F.; Lin, Y. Dissolved soil organic carbon and nitrogen were affected by conversion of native forests to plantations in subtropical China. Can. J. Soil Sci. 2010, 90, 27-36. [CrossRef]

25. Zhang, H.; Qian, Z.; Zhuang, S. Effects of soil temperature, water content, species, and fertilization on soil respiration in bamboo forest in subtropical China. Forests 2019, 11, 99. [CrossRef]

26. Qian, Z.Z.; Zhuang, S.Y.; Gui, R.Y.; Tang, L.Z. Effect of soil aeration treatment on the physiological and biochemical characteristics of Phyllostachys praecox under the organic material mulching. Plant Soil 2021, 459, 357-369. [CrossRef]

27. Jiang, P.K.; Xu, Q.F.; Xu, Z.H.; Cao, Z.H. Seasonal changes in soil labile organic carbon pools within a Phyllostachys praecox stand under high rate fertilization and winter mulch in subtropical China. Forest Ecol. Manag. 2006, 236, 30-36. [CrossRef]

28. Jiang, P.; Ye, Z.; Xu, Q. Effect of mulching on soil chemical properties and enzyme activities in bamboo plantation of Phyllostachy praecox. Commun. Soil Sci. Plan Anal. 2002, 33, 3135-3145. [CrossRef]

29. Gui, R.; Sun, X.; Zhuang, S. Soil acidification in Phyllostachys praecox f. preveynalis cultivation with intensive management. Commun. Soil Sci. Plan Anal. 2013, 44, 3235-3245. [CrossRef]

30. Silgram, M.; Shepherd, M. The effects of cultivation on soil nitrogen mineralization. Adv. Agron. 1999, 65, 267-311. [CrossRef]

31. Shi, Y.; Zhang, X.; Wang, Z.; Xu, Z.; He, C.; Sheng, L.; Liu, H.Y.; Wang, Z. Shift in nitrogen transformation in peatland soil by nitrogen inputs. Sci. Total Environ. 2020, 764, 142924. [CrossRef]

32. Walkley, A.; Black, I.A. An examination of the degtjareff method for determining soil organic matter, and a proposed modification of the chromic acid titration method. Soil Sci. 1934, 37, 29-38. [CrossRef]

33. Lu, R.K. Analytical Methods for Soil and Agro-Chemistry; China Agricultural Science and Technology Press: Beijing, China, 1999. (In Chinese)

34. Stanford, G.; Smith, S.L. Nitrogen mineralization potentials of soils. Soil Sci. Soc. Am. Proc. 1972, 36, 465-470. [CrossRef]

35. Chen, Z.; Li, Y.; Chang, S.X.; Xu, Q.; Li, Y.; Ma, Z.; Qin, H.; Cai, Y. Linking enhanced soil nitrogen mineralization to increased fungal decomposition capacity with Moso bamboo invasion of broadleaf forests. Sci. Total Environ. 2021, 771, 144779. [CrossRef] [PubMed]

36. Stevenson, F.J. Nitrogen-organic forms. In Methods of Soil Analysis, Part 3 Chemical Methods; Bigham, J.M., Ed.; Soil Science Society of America, American Society of Agronomy: Madison, WI, USA, 1996; pp. 1185-1200.

37. Wang, S.; Jiao, L.; Jin, X.; Niu, D. Characteristics of organic nitrogen fractions in sediments of the shallow lakes in the middle and lower reaches of the Yangtze River area in China. Water Environ. J. 2012, 26, 473-481. [CrossRef]

38. Li, H.; Han, Y.; Cai, Z. Nitrogen mineralization in paddy soils of the Taihu Region of China under anaerobic conditions: Dynamics and model fitting. Geoderma 2003, 115, 161-175. [CrossRef]

39. Zhu, Z.L. Nitrogen mineralization and prediction of nitrogen availability of Taihu region. Acta Pedol. Sin. 1982, 21, 29-36. (In Chinese)

40. Richter, J.; Nuske, A.; Boehmer, U.; Wehrmann, J. Simulation of nitrogen mineralization and transport in Loess-Parabrownearthes: Plot experiments. Plant Soil 1980, 54, 329-337. [CrossRef] 
41. Lindemann, W.C.; Connell, G.; Urquart, N.S. Previous sludge addition effect on nitrogen mineralization in freshly amends soil. Soil Sci. Soc. Am. J. 1988, 52, 109-112. [CrossRef]

42. Song, Y.; Yao, Y.F.; Qin, X.; Wei, X.R.; Jia, X.X.; Shao, M.G. Response of carbon and nitrogen to afforestation from 0 to $5 \mathrm{~m}$ depth on two semiarid cropland soils with contrasting inorganic carbon concentrations. Geoderma 2020, 357, 113940. [CrossRef]

43. Holubík, O.; Podrázský, V.; Vopravil, J.; Khel, T.; Remeš, J. Effect of agricultural lands afforestation and tree species composition on the soil reaction, total organic carbon and nitrogen content in the uppermost mineral soil profile. Soil Water Res. 2014, 9, 192-200. [CrossRef]

44. Don, A.; Schumacher, J.; Freibauer, A. Impact of tropical land-use change on soil organic carbon stocks-A meta analysis. Glob. Chang. Biol. 2011, 17, 1658-1670. [CrossRef]

45. Zhang, Y.; Jiang, P.; Li, Y.; Wu, J.; Xu, K.; Hill, S.; Wang, H. Chemistry of decomposing mulching materials and the effect on soil carbon dynamics under a Phyllostachys praecox bamboo stand. J. Soil Sediment. 2013, 13, 24-33. [CrossRef]

46. Li, Y.; Jiang, P.; Chang, S.X.; Wu, J.; Lin, L. Organic mulch and fertilization affect soil carbon pools and forms under intensively managed bamboo (Phyllostachys praecox) forests in southeast China. J. Soil Sediment. 2010, 10, 739-747. [CrossRef]

47. Zhang, T.; Li, Y.; Chang, S.X.; Jiang, P.; Zhou, G.; Liu, J.; Lin, L. Converting paddy fields to Lei bamboo (Phyllostachys praecox) stands affected soil nutrient concentrations, labile organic carbon pools, and organic carbon chemical compositions. Plant Soil 2013, 367, 249-261. [CrossRef]

48. Pan, G.; Li, L.; Wu, L.; Zhang, X. Storage and sequestration potential of topsoil organic carbon in China's paddy soils. Glob. Chang. Biol. 2003, 10, 79-92. [CrossRef]

49. Li, S.; Ai, S.; He, H. Soil's nitrogen mineralization processes under continuously waterlogged incubation conditions. Acta Univ. Agric. Boreali-Occident. 1999, 27, 1-5. (In Chinese)

50. Cameron, K.C.; Di, H.J.; Moir, J.L. Nitrogen losses from the soil/plant system: A review. Ann. Appl. Boil. 2013, 162, 145-173. [CrossRef]

51. Liu, Q.; Qi, L.; Hu, X.; Zhang, Y. Effects of nitrogen fertilization on nitrification and denitrification in Phyllostachys edulis forests. J. Nanjing For. Univ. (Nat. Sci. Ed.) 2017, 41, 82-88. (In Chinese) [CrossRef]

52. Kader, M.A.; Senge, M.; Mojid, M.A.; Ito, K. Recent advances in mulching materials and methods for modifying soil environment. Soil Tillage Res. 2017, 168, 155-166. [CrossRef]

53. Zhang, Q.C.; Wang, G.H.; Xie, W.X. Soil organic N forms and N supply as affected by fertilization under intensive rice cropping system. Pedosphere 2006, 16, 345-353. [CrossRef]

54. Rovira, P.; Vallejo, V.R. Labile and recalcitrant pools of carbon and nitrogen in organic matter decomposing at different depths in soil: An acid hydrolysis approach. Geoderma 2002, 107, 109-141. [CrossRef]

55. Stevenson, F.J. Humus Chemistry: Genesis, Composition, Reactions; Wiley: New York, NY, USA, 1994.

56. Geisseler, D.; Horwath, W.R.; Joergensen, R.G.; Ludwig, B. Pathways of nitrogen utilization by soil microorganisms-A review. Soil Biol. Biochem. 2010, 42, 2058-2067. [CrossRef]

57. Farzadfar, S.; Knight, J.D.; Congreves, K.A. Soil organic nitrogen: An overlooked but potentially significant contribution to crop nutrition. Plant Soil 2021, 462, 7-23. [CrossRef]

58. Mulvaney, R.; Khan, S.; Hoeft, R.; Brown, H. A soil organic nitrogen fraction that reduces the need for nitrogen fertilization. Soil Sci. Soc. Am. J. 2001, 65, 1164-1172. [CrossRef]

59. Li, L.; Li, S. Nitrogen mineralization from animal manures and its relation to organic N fractions. J. Integr. Agric. 2014, 13, 2040-2048. [CrossRef]

60. Wu, S.; Suo, Y.; Liang, G.; Zheng, Z.; Xu, Z.; Lu, S. Soil acidification and buffering capacity of bamboo plantation soils under intensive cultivation management. Chin. J. Soil Sci. 2012, 43, 1120-1125. (In Chinese)

61. Yan, E.R.; Wang, X.H.; Huang, J.J.; Li, G.Y.; Zhou, W. Decline of soil nitrogen mineralization and nitrification during forest conversion of evergreen broad-leaved forest to plantations in the subtropical area of Eastern China. Biogeochemistry 2008, 89, 239-251. [CrossRef]

62. Miller, A.J.; Cramer, M.D. Root nitrogen acquisition and assimilation. Plant Soil 2005, 274, 1-36. [CrossRef]

63. Jämtgård, S.; Näsholm, T.; Huss-Danell, K. Characteristics of amino acid uptake in barley. Plant Soil 2008, 302, 221-231. [CrossRef]

64. Aulakh, M.S.; Doran, J.W.; Walters, D.T.; Mosier, A.R.; Francis, D.D. Crop residue type and placement effects on denitrification and mineralization. Soil Sci. Soc. Am. J. 1991, 55, 1020-1025. [CrossRef]

65. Baggs, E.M.; Rees, R.M.; Smith, K.A.; Vinten, A.J.A. Nitrous oxide emission from soils after incorporating crop residues. Soil Use Manag. 2000, 16, 82-87. [CrossRef]

66. Aciego Pietri, J.C.; Brookes, P.C. Nitrogen mineralisation along a pH gradient of a silty loam UK soil. Soil Biol. Biochem. 2008, 40, 797-802. [CrossRef]

67. Rousk, J.; Bååth, E.; Brookes, P.C.; Lauber, C.L.; Lozupone, C.; Caporaso, J.G.; Knight, R.; Fierer, N. Soil bacterial and fungal communities across a pH gradient in an arable soil. ISME J. 2010, 4, 1340-1351. [CrossRef] [PubMed]

68. Chen, J.; Wu, Q.; Li, S.; Ge, J.; Liang, C.; Qin, H.; Xu, Q.; Fuhrmann, J.J. Diversity and function of soil bacterial communities in response to long-term intensive management in a subtropical bamboo forest. Geoderma 2019, 354, 113894. [CrossRef]

69. Rasouli-Sadaghiani, M.H.; Moradi, N. Effect of poultry, cattle, sheep manures and sewage sludge on N mineralisation. Chem. Ecol. 2014, 30, 666-675. [CrossRef]

70. Li, H.; Han, Y.; Roelcke, M.; Cai, Z. Net nitrogen mineralization in typical paddy soils of the Taihu Region of China under aerobic conditions: Dynamics and model fitting. Can. J. Soil Sci. 2008, 88, 719731. [CrossRef] 
71. Serna, M.D.; Pomares, F. Nitrogen mineralization of sludge-amended soil. Bioresour. Technol. 1992, 39, 285-290. [CrossRef]

72. Nendel, C.; Reuter, S. Kinetics of net nitrogen mineralisation from soil-applied grape residues. Nutr. Cycl. Agroecosyst. 2007, 79, 233-241. [CrossRef]

73. Zhang, Y.; Xu, W.; Duan, P.; Cong, Y.; An, T.; Yu, N.; Zou, H.; Dang, X.; An, J.; Fan, Q.; et al. Evaluation and simulation of nitrogen mineralization of paddy soils in Mollisols area of Northeast China under waterlogged incubation. PLoS ONE 2017, 12, e0171022. [CrossRef] 